\title{
Management of economic and financial risk of investments in assets for extraction of non-metallic mineral extracts
}

\author{
Gestión del riesgo económico-financiero de inversiones \\ en activos para extracción de minerales no metálicos
}

\author{
Izabelle Martinez Martinez $^{1} \quad$ Gislaine Cristina Batistela ${ }^{1} \quad$ Danilo Simões $^{1 *}$
}

Recibido 10 de julio de 2019, aceptado 12 de agosto de 2021

Received: July 10, 2019 Accepted: August 12, 2021

\begin{abstract}
The investment projects evaluation in real assets is essential for decision making; however, undoubtedly, it is a process whose components have interdependent relationships, which generate uncertainties that can lead to the wrong acceptance or rejection of the investment. This study aimed to apply the Monte Carlo simulation to the risk incorporation into the economic and financial evaluation of an investment project in mineral assets under conditions of uncertainties, with a view to the obtained returns measurement. Thus, the evaluation was based on the projection of discounted cash flow, which allowed the adoption of methods commonly used to evaluate real assets that consider the time value of the money. The economicfinancial risk incorporation was performed using a stochastic and dynamic mathematical model, and the Monte Carlo method was used to generate values from probability distributions. The results showed that the investment project in mineral assets is economically feasible by adding value to investors.
\end{abstract}

Keywords: Evaluation approaches, uncertainty, Monte Carlo, stochastic control, net present value.

\section{RESUMEN}

La evaluación de proyectos de inversión en activos reales es imprescindible para la toma de decisiones, sin embargo, indudablemente, es un proceso cuyos componentes poseen relaciones de interdependencia, las cuales generan incertidumbres que pueden conducir a la aceptación o rechazo equivocado de la inversión. De este modo, se pretendía aplicar la simulación de Monte Carlo para la incorporación del riesgo a la evaluación económico-financiera de un proyecto de inversiones en activos minerales bajo condiciones de incertidumbre, con miras a la medición de las franjas de valores de los retornos obtenidos. Así, la evaluación fue pautada en la proyección del flujo de caja descontado, que permitió adoptar métodos comúnmente utilizados para la evaluación de activos reales que consideran el valor del dinero a lo largo del tiempo. La incorporación del riesgo económico-financiero, fue realizada por medio de un modelo matemático estocástico y dinámico, ejecutándose el método de Monte Carlo para la generación de valores a partir de distribuciones de probabilidades. Los resultados demostraron que el proyecto de inversiones en activos minerales es viable económicamente por agregar valor a los inversores.

Palabras clave: Enfoques de evaluación, incertidumbre, Monte Carlo, control estocástico, valor presente neto.

\footnotetext{
1 São Paulo State University (Unesp), Campus of Itapeva. Itapeva, Brazil.

E-mail: martinez.izabelle@outlook.com; gislaine.batistela@unesp.br; danilo.simoes@unesp.br

* Autor de correspondencia: danilo.simoes@unesp.br
} 


\section{INTRODUCTION}

The investment valuation considers the adequation, efficiency, and feasibility of a particular project, and evaluates the project's impact on the total effectiveness, prosperity, and financial stability of a company through management indicators [1-2]. Therefore, the investment project analysis consists of a special type of budget. Its differential is due to the factor that explicitly considers the time factor, i.e., by including the money value over time in the formation of the cash flows involved in the project, focusing on strategic alignment [3-4].

Thus, the main motivation for using discounted cash flow techniques is based on considering money value over time [5]. Nevertheless, according to [6], the traditional methods, which are calculated using cash flow, such as net present value (NPV), do not always capture the managerial complexity of an investment decision and underestimating the value generated by a project [7]. A large part of the papers address the static and deterministic version of the problem, i.e., the DCF method fails to capture the uncertainties of the input data, not proposing the consideration to the probability of variations occur in the performed projections [8-9].

It is necessary to use appropriate techniques to evaluate investment projects exposed to an environment that presents uncertainties and risks to the investor. Mining projects are known to require constant risk assessment as they are embedded in an environment that exhibits various types of uncertainties that influence the value of a mining investment project. In the cases of these projects involving high financial investments, the sensitivity and risk analysis is of paramount importance since it aims to evaluate the uncertainties and impacts in the projects.

Therefore, accounting for the risks of a mining project is primordial during the conduct of the investment analysis. There must be an understanding that effective risk management does not apply to the dismissal of risk, since the withdrawal of risk, however, implies a lack of economic sensitivity because what is potentially profitable is, by definition, risky and somewhat which does not pose a risk does not bring tangible benefits [10]. In view of this, risk analysis through simulation of different scenarios is a method to minimize risk factors and maximize opportunity factors, as well as the probability of success of a project [11-12].

In view of the above, [13] demonstrate that the Monte Carlo simulation application is adequate for evaluating of mining projects since it presents a broader context of cash flows estimation in the investments evaluation. The simulation is adopted to solve incomplete information and allow the investor to better understand the risk and the uncertainty in the estimation of discounted cash flow. [14-15] explain that the Monte Carlo simulation evaluates the phenomena that a probabilistic behavior can characterize.The generation of random numbers, allows solving a large number of problems with the simulation of scenarios and the subsequent calculation of an expected value.

The benefit of using this method is the admission and implantation of additional hypotheses in the forecasts, supplying the static character of the discounted cash flow. Therefore, the study is justified by the need to adopt a sampling technique to evaulate an investment project inserted in an environment of uncertainties. The objective of this study was to evaluate an investment project of an extractive industry by executing the Monte Carlo simulation so that the associated uncertainties are weighted to measure economic and financial risks.

\section{METHODOLOGICAL PROCEDURES}

The research consisted of a study case that, according to [16], is an in-depth study of one or a few objects, which enables the detailed analysis of the characteristics of the object. In this perspective, the approach used was of a quantitative nature, that in the understanding of [17], the choice for quantitative research is justified because it has a statistical bias that organizes, summarizes, and interprets the numerical data collected. The semi-structured interview technique was used in consonance with [18] to obtain the data.

As a study object, the evaluation of investments in mineral assets weighted matrices of technical coefficients of an extractive industry that performs the extraction and beneficiation of mineral goods, located in the State of São Paulo, Brazil. The economic activity of the industry, according to 
the national classification of economic activities, valid in the country is the extraction of limestone, registered under the number 0810-0/04.

\section{Economic and financial evaluation}

The economic-financial valuation was based on the discounted cash flow, with projected values for a useful life mineral deposit of 20 years, characterized as unconventional. According to [19], the flows showed signals changes throughout the investment's useful life.

These flows were organized as a result of the sum of cash inflows and outflows, i.e., revenues generated from the sale of the mineral, taxes, capital expenditure (CAPEX), working capital, depreciation of fixed assets, administrative costs, and environmental recovery costs, considered as an indirect cost. The operating expenses (OPEX) were drilling, blasting with explosives, blasting with mechanical equipment, mineral transport, direct labor, and mineral good beneficiation.

Monetary values were expressed in US dollars (US \$) as the reference currency for the financial market [20]. Therefore, the exchange rate of the foreign currency made available by the Central Bank of Brazil [21] at the sale price, measured in units and fractions of the national currency, was BRL \$ 3.1408 as of 10/04/2017.

The project risk-adjusted discount rate, that is, the return required for the investment project was determined using the weighted average cost of capital (WACC). Therefore, according to [22] and [23], the capital asset pricing model (CAPM) described in Equation 1 as $k_{s}$ was calculated according to [24].

$$
k_{s}=r_{f}+\beta\left(r_{m}-r_{f}\right)+a_{B r}
$$

Where:

$k_{s} \quad$ is the opportunity cost of ordinary capital financing;

$k_{f} \quad$ is the risk-free rate of return;

$\beta \quad$ is the systematic coefficient of the asset;

$r_{m} \quad$ is the expected rate of return for the market portfolio;

$\left(r_{m}-r_{f}\right)$ is risk premium in the market;

$a_{B r} \quad$ is the country risk premium.

Consequently, the empirical measurement of the beta was calculated by least-squares regression analysis to obtain the coefficient of regression of the equation of the linear characteristic line, calculated in accordance with [25] (Equation 2).

$$
\beta=\frac{\operatorname{Cov}\left(r_{m}, r_{f}\right)}{\sigma_{m^{2}}}
$$

where:

$r_{f}$ are the returns on the asset for which it is desired to calculate the expected return;

$\sigma_{\mathrm{m}}{ }^{2}$ is the variance of the market portfolio.

Thus, the economic-financial risk was calculated considering that the extractive industry had a liability; that is, the leveraged beta was calculated that is adopted for companies with debt (Equation 3).

$$
\beta_{L}=\beta_{U}\left[1+\left(\frac{B}{N E}\right) \times(1-T R)\right]
$$

Where:

$\beta_{\mathrm{L}}$ is the leveraged beta;

$\beta_{U}$ is the beta coefficient of a company with no debts (unleveraged beta);

$B$ are the burdensome liabilities;

$N E$ is the net equity.

$T R$ is a tax rate on capital gain.

With:

$$
\beta_{U}=\frac{\beta_{L}}{\left[1+\left(\frac{B}{N E}\right) \times(1-T R)\right]}
$$

Finally, the company's WACC reflected the weighted average cost of funding sources, determined by Equation 5, according to [26].

$W A C C=k_{b}(1-T R) \frac{M V}{(M V+N E)}+k_{s} \frac{N E}{(M V+N E)}(5)$

Where:

$k_{b} \quad$ is the cost of capital from the creditor; $M V \quad$ is the market value of debt;

$k_{s} \quad$ is the shareholder's cost of capital; $\frac{M V}{(M V+N E)}$ is the proportion of the asset financed

$N E$

$\frac{N E+N E)}{(M V}$ is the proportion of owner-financed assets. 
The project was evaluated using techniques of investments in real assets that can be considered sophisticated, that is, take into account the value of money over time. Thus, we considered the net present value, which according to [27], reflects the absolute monetary value added to the investment (Equation 6).

$$
N P V=\sum_{j=1}^{n} \frac{C F_{j}}{(1+W A C C)^{j}}-I_{0}
$$

Where:

$N P V$ is the net present value (US\$);

$n \quad$ is the number of projetcted periods;

$j \quad$ is the period in which costs and revenues occur;

$C F_{j}$ is the cash flow for each period;

$I_{0} \quad$ is the investment processed at the focal date.

Due to the investment project having unconventional cash flows, the modified internal rate of return was applied because it was intrinsic to the evaluated condition and, in particular, to provide investors a more realistic rate of return. In addition, it eliminates the problem of multiple rates of return, consistent with [28] in Equation 7.

$$
M I R R=\left[\frac{\sum_{j=1}^{n} R E V\left(1+i_{r}\right)^{n-j}}{\sum_{j=1}^{n} \frac{\left|c_{j}\right|}{\left(1+i_{f}\right)^{j}}}\right]^{\frac{1}{n}}-1
$$

MIRR is the modified internal rate of return (\%);

$i_{r} \quad$ is the reinvestment rate;

$i_{f} \quad$ is the rate of funding;

$R E V$ is the revenue (net positive value, in each period " $j$ " of the cash flow);

$C_{j} \quad$ is the cost (net negative value, in each period " j" of the cash flow).

In this perspective, the historical series of the fixed interest rate, plus the monetary correction factor, according to the Brazilian financial system, between 02/01/2018 and 03/31/2018 to design the rate of reinvestments, and data referring to the basic interest rate of the Brazilian economy, were observed between January and July 2018 to obtain the rate inherent in fundraising, both of which were made available by the Central Bank of Brazil [29].

Mathematically, the NPV and the MIRR lead the decision-maker to accept or reject investment projects in real assets; however, these methods do not allow the NPV value to be obtained per monetary unit spent. Thus, as a measure of performance, the profitability index was used to measure the aggregate value per dollar applied to the investment project, detailed in Equation 8, according to [30].

$$
P I=\frac{\sum_{j=1}^{n} \frac{C F_{j}}{(1+W A C C)^{j}}}{I_{0}}
$$

$P I$ is the profitability index.

\section{Economic and financial risk assessment}

To incorporate the economic-financial risk evaluation, the cash flow was developed from a stochastic and dynamic mathematical model, that is, with probabilistic input variables, that through algebraic equations allowed to obtain the outputs. Therefore, the inputs that allowed quantification of the economicfinancial risk of the investment project in mineral assets were: The price of the mineral good (US \$ per year); production of the mineral good (t per year); CAPEX (US \$), OPEX (US \$ per year); working capital (US \$ per year); and mine closure plan (US $\$$ per year). According to [31], the distribution used was the symmetric triangular because it is easy to understand and commonly used in uncertainty analyzes when there is no plausible information about the probability distribution of the variables weighted in the stochastic model. Regarding the outputs, the quantitative methods of evaluating investments in real assets (NPV, MIRR, and PI) were considered.

The time-series data were decomposed through Trend ( $\mathrm{T}$ ) according to [32] to design the rate of reinvestment and financing of cash flows. Thus, the integrated autoregressive process of the ARIMA moving averages $(\mathrm{p}, \mathrm{d}, \mathrm{q})$ was adopted in accordance with [33], with the statistical model selected by the Bayesian Information Criterium (BIC) in the due form recommended by [34].

The Monte Carlo simulation method was applied with 100,000 iterations executed through @Risk 
Copyright (C) 2017 software [35], generating 100,000 pseudorandom numbers. The standard of the random number generator was the Mersenne Twister, according to [36], ensuring the same initial parameter for the executed model.

Because NPV is the method traditionally adopted evaluating investment projects in real assets, a probability distribution was adjusted by the BIC selection criterion. In order to measure the degree of linear association between inputs and NPV, the Spearman correlation coefficient [37] was used at a significance level of $5 \%$.

\section{RESULTS AND DISCUSSION}

\section{Investment project discount rate}

The cost of equity was based on: The arithmetic mean of the return rate of a risk-free asset of $1.82 \%$ per year according to the historical series Annual Return on Treasury bonds 10Y US; in the systematic asset ratio calculated from the total average beta of the industrial goods sector in the segment of construction products in the Brazilian stock market, which resulted in a leveraged beta of 0.94 ; in the annualized rate of return for the market portfolio of $2.62 \%$ per year expected for the next 10 years according to the $\mathrm{S} \& \mathrm{P}$ Global Natural Resources Index; and the arithmetic mean of the $2.97 \%$ per year risk premium based on the Emerging Markets Bond Index - EMBI + Br. Therefore, by weighing the cost of third-party capital of $8 \%$ per year and the liabilities onerous of $20 \%$, the WACC of the investment project was $5.54 \%$ per year.

\section{Sensitivity analysis}

When evaluating the sensitivity of the input variables of the stochastic model (Figure 1), [38] point out that the Spearman correlation coefficient is generally used when the distribution of the variables is not normal since it corresponds to a non-parametric method to calculate the correlation of the data, that is, it measures the degree of linear association between two variables (X and $\mathrm{Y}$ ) and varies between -1 and 1 .

It was found that the production and the price of the mineral good have moderate positive Spearman correlation coefficients $(0.68)$ concerning the NPV, that is, establish a relation directly proportional to the output variable under evaluation. According to [39], the magnitude of Spearman's correlation coefficient can be interpreted as follows: Very strong if greater than 0.90; a strong ratio between 0.90 and 0.71 ; a moderate was between 0.70 and 0.51 ; weak if between 0.50 and 0.31 , very weak or not significant if less than or equal to 0.30 .

The CAPEX, OPEX expended with the processing, and the administrative costs are variables that correlate negatively with the NPV; that is, as the monetary values of these variables increase, the NPV value will decrease, showing a relation of inversely proportional variables. Although these variables had a very weak correlation coefficient $(<0.30)$, it is essential to monitor the expenses demanded since the absolute monetary values can increase the economic-financial risk of the investment project.

\section{Risk analysis}

Figure 2 shows the probability density function of the NPV in which the adherence of the data to the Normal distribution was proved employing the Kolmogorov-Smirnov test for the value of NPV $(\mathrm{KS}=0.021)$ and $\mathrm{BIC}=3,245$, with a mean value of NPV of US $\$ 8,202,436 \pm 2,692,402$ which has a symmetric curve around the mean. Therefore,

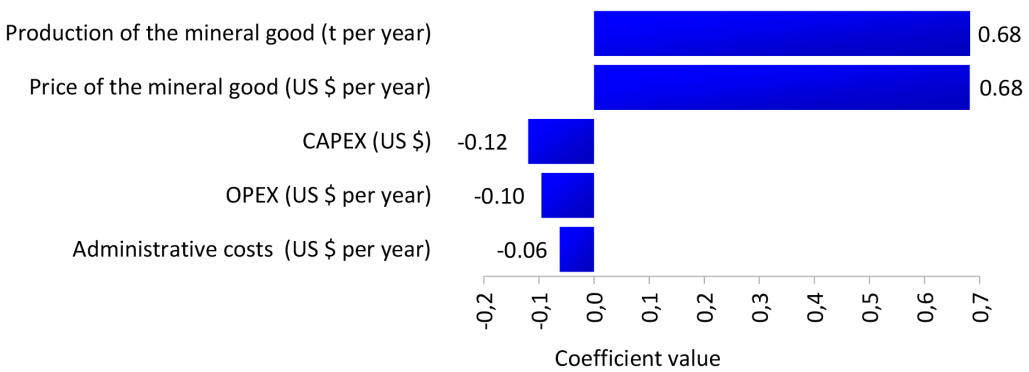

Figure 1. Spearman's correlation coefficients of the five variables that most influenced the NPV of the investment project. 


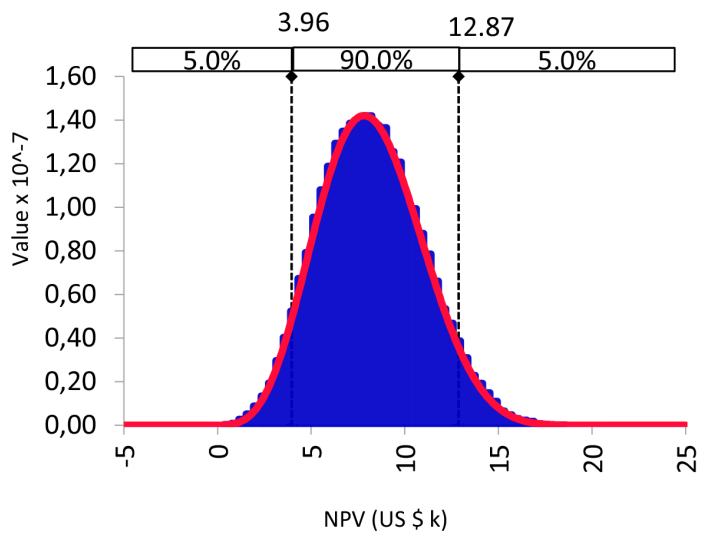

Figure 2. Probability density function of the NPV investment project.

the NPV resulted in a maximum value of US $\$ 19,812,128$ and a minimum value of US $\$ 358,064$, with an asymmetry of 0.2163 and kurtosis of 2.7683 , which corroborates the normality of the data, since the value of kurtosis should approach 3 to assume that the data follow a Normal distribution, while the asymmetry value should approach zero [40].

The knowledge of the NPV distribution has great relevance since this parameter indicates if the returns obtained with the investment will be enough to compensate the operational costs and the investment realized in present values [41]. Thus, the project of investments in mineral assets showed economicfinancial feasibility since the NPV result presents positive values, indicating the project's economics.

Concerning the value of MIRR, it is observed in Figure 3 that this was higher than the value of WACC; that is, the mean value of MIRR was $11.59 \% \pm 1.45$, thus $6.05 \%$ higher than WACC. [42] compare the MIRR with the expected rate of return and emphasize that when the value of the first is higher than the value of the second, the investment is economically feasible. [43] emphasize that MIRR transforms the original multi-period project into a project that contains only a negative initial cash flow and a positive final cash flow. In this sense, the investment project in mineral assets indicated a $100 \%$ probability of the MIRR being superior to the WACC, which ensures the maximization of the company's market value based on the applied capital.

Additionally, the MIRR presents a centralized value indicating the symmetry in the data distribution and, consequently, less variability. This condition was corroborated by the adherence to the data distribution adjusted to the Weibull distribution employing the Kolmogorov-Smirnov test K-S = 0.004 and $\mathrm{BIC}=-563,988$.

The accumulated frequency distribution graph of the profitability index (Figure 4), according to [44], assists in establishing cutoffs with a given frequency in the values of a variable. This parameter represents the relationship between the NPV and the initial investment. Thus, an index greater than 1 provides the ability of the investment to generate profits.

The profitability index expresses the net present value of an initial expense in a monetary unit. It characterizes the relationship between the net present value and the investment funds that

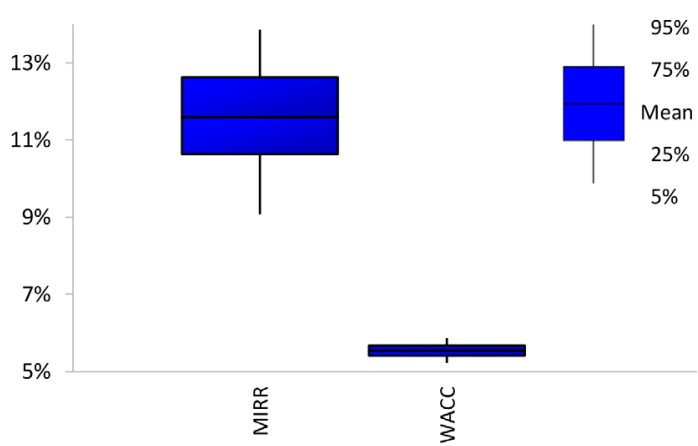

Figure 3. Boxplot of MIRR and WACC to evaluate the investment project.

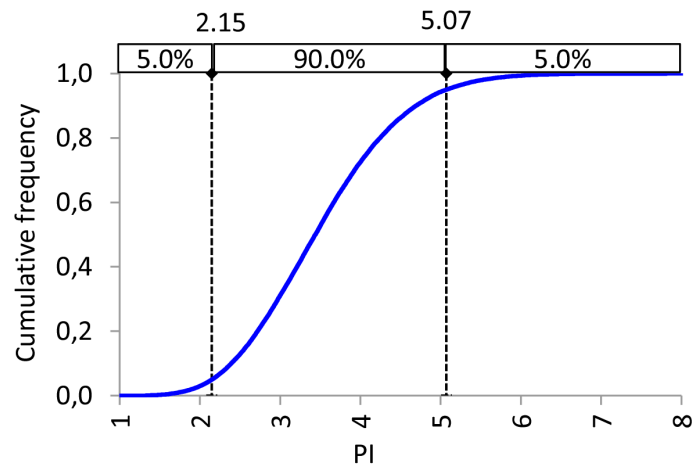

Figure 4. Accumulated frequency distribution of the PI. 
generate the volume of NPV, and completing the efficiency analysis in relative terms, in the form of net benefit per unit of relative measure to the cost of investment [45].

In this light, the average PI was $3.50 \pm 0.89$, thus providing a return of US $\$ 2.50$ to investors for each dollar invested. In view of the preceding, it appears that the probability of the investment being rejected as investing losses $(\mathrm{PI}<1)$ is zero. In addition, it was observed that $90 \%$ of the stochastic results of the profitability index are between 2.15 and 5.07.

\section{CONCLUSIONS}

The techniques of investments valuation are usually based on the discounted cash flow. However, investment projects in mineral assets are embedded in an environment of uncertainties. Therefore, it becomes imperative to measure risks from the various sources of uncertainty, to overcome deficiencies in deterministic cash flows, and, above all, to mitigate the respective risks.

The study proposed applying the Monte Carlo simulation to the risk incorporation into the economic and financial evaluation of an investment project in mineral assets under conditions of uncertainties, with a view to the measurement of the ranges of returns.

Employing the Spearman correlation coefficient, it was verified that the stochastic variable price and production of the mineral goods were those that most positively influenced the NPV; however, the CAPEX was the variable that had the highest negative correlation with the NPV.

The NPV probability density curve resulted in positive values, which indicated the implementation of the investment project in mineral assets since the probability of the project not adding value to investors was null.

The MIRR converged to the viability of the investment project, providing investors with a higher return than the required minimum attractiveness rate by providing values higher than the WACC.

By demonstrating that the return for each monetary unit invested is greater than 1, the profitability index corroborated the investor's ability to invest in generating profits. There will be available financial resources after payment of all costs, expenses, charges, and depreciation.

\section{ACKNOWLEDGMENTS}

This work was carried out with the support of process 2017/20323-0, Fundação de Amparo à Pesquisa do Estado de São Paulo.

\section{REFERENCES}

[1] R. Rajnoha, M. Jankovský and M. Merková. "Economic comparison of automobiles with electric and with combustion engines: An analytical study". Procedia Social and Behavioral Sciences. Vol. 109, pp. 225-230. 2014. DOI: 10.1016/j.sbspro.2013.12.449.

[2] A.M.N. González, M.S. Fleitas Triana, G. Gémar Castillo, J.C. Negrón González, V. García Fenton y Y. Trujillo Reyna. "Identificación de costos ocultos a partir de un estudio de organizacióndel trabajo en una empresa del sector farmacéutico en Cuba". Ingeniare. Revista chilena de ingeniería. Vol. 26, pp. 6-20. 2018. DOI: 10.4067/ S0718-33052018000 100006.

[3] R.C. Moreira, B. Santos Reis, V. Ferraz Souza, Roberta Fialho e C.V. Leocádio Rigueira. "Viabilidade econômica da agroindústria familiar rural de frutas na zona da mata mineira". Revista de Economia e Agronegócio. Vol. 5 No 2, pp. 187-206. 2015. DOI:10.25070/rea.v5i 2.102.

[4] A.M. Léon, D. Nogueira Rivera, A. Hernández-Nariño y R. Comas Rodríguez. "Procedimiento para la gestión por procesos: Métodos y herramientas de apoyo". Ingeniare. Revista chilena de ingeniería. Vol. 27, pp. 328-342, 2019. DOI: 10.4067/ S0718-33052019000200328.

[5] R. Batra and S. Verma. "Capital budgeting practices in Indian companies". IIMB Management Review. Vol. 29, pp. 29-44. 2017. DOI: 10.1016/j.iimb.2017.02.001.

[6] G. Vedovoto y D. Prior. "Opciones reales: Una propuesta para valorar proyectos de I+D en centros públicos de investigación agraria". Contaduría y Administración. Vol. $60 \mathrm{~N}^{\circ} 1$, pp. 145-179. 2015.

[7] D. Simões, A.C. Cabral and P.A. Oliveira. "Citriculture economic and financial 
evaluation under conditions of uncertainty". Revista Brasileira de Fruticultura. Vol. $37 \mathrm{~N}^{\circ}$ 4, pp. 859-869. 2015. DOI: 10.1590/0100-2945-257/14.

[8] C. Ugwuegbu. "Segilola gold mine valuation using Monte Carlo simulation approach". Mineral Economics. Vol. 26, pp. 39-46. 2013. DOI: $10.1007 / \mathrm{s} 13563-013-0030-8$.

[9] M.F.S. Silva, F.M. Menezes Pereira, P. Chambal Rodriguez y F. Henrique Pereira. "Un enfoque de optimización y simulación utilizando algoritmo genéticopara el problema de secuenciamiento dinámico con demanda estocástica". Ingeniare. Revista chilena de ingeniería. Vol. 27, pp. 217-222. 2019. DOI: 10.4067/S0718-33052019000200217.

[10] P. Szymański. "Risk management in construction projects". Procedia Engineering. Vol. 208, pp. 174-182. 2017. DOI: 10.1016/j. proeng.2017.11.036.

[11] J. Park, B. Park, Y. Cha and Ch. Hyun. "Risk factors assessment considering change degree for mega-projects". Procedia Social and Behavioral Sciences. Vol. 218, pp. 50-55. 2016. DOI: 10.1016/j. sbspro.2016.04.009.

[12] F.Y.K. Takigawa, E. Aranha Neto, R.C. Fernandes, D. de Campos y M. Cardoso. "Analysis of the Financial Viability of a Photovoltaic System to a Consumer Unit in South Brazil". Ingeniare. Revista chilena de ingeniería. Vol. 27, pp. 131-141. 2019. DOI: 10.4067/S0718-33052019000100131.

[13] S.S. Shaffie and S.H. Jaaman. "Monte Carlo on Net Present Value for capital investment in Malaysia". Procedia - Social and Behavioral Sciences. Vol. 219, pp. 688-693. 2016. DOI: 10.1016/j.sbspro.2016.05.052.

[14] S. Garcia, N.R. Barros e P.R.B. Lustosa. "Aplicabilidade do método de simulação de monte carlo na previsão dos custos de produção de companhias industriais: O caso da companhia Vale do Rio Doce". Revista de Contabilidade e Organizações. Vol. 4 $\mathrm{N}^{\mathrm{o}}$ 10, pp. 152-173. 2010. DOI: $10.11606 /$ rco.v4i10.34781.

[15] J. Martinez Velasco, J. Corea Araujo y S. Bedoui. "Lightning performance analysis of transmission lines usingthe Monte Carlo method and parallel computing". Ingeniare. Revista chilena de ingeniería.
Vol. 26, pp. 398-409. 2018. DOI: $10.4067 /$ S0718-33052018000300398.

[16] A.C. Gil. "Como Elaborar Projetos de Pesquisa”. Atlas. 5ta edição. São Paulo, Brasil. ISBN: 9788522458233 2010. 2010.

[17] G.A. Martins e C.R. Theóphilo. "Metodologia da investigação científica para ciências sociais aplicadas". Atlas. 1ra edição. São Paulo, Brasil. ISBN: 9788597008111. 2007.

[18] E.J. Manzini. "Uso da entrevista em dissertações e teses produzidas em um programa de pós-graduação em educação". Revista Percurso. Vol. 4 No 2, pp. 149-171. 2012. DOI: $10.4025 /$ revpercurso.v4i2.18577.

[19] A.N. Müller e L.R. Antonik. "Matemática financeira". Saraiva. 1ra edição. São Paulo, Brasil. ISBN: 9788502157071. 2017.

[20] D. Simões, R.B.G. Silva e M.R. Silva. "Composição do substrato sobre o desenvolvimento, qualidade e custo de produção de mudas de Eucalyptus grandis Hill ex Maiden $\times$ Eucalyptus urophylla S.T. Blake". Ciência Florestal. Vol. 22 NN $^{o}$ 1, pp. 91-100, 2012. DOI: 10.5902/198050 985082.

[21] Banco Central do Brasil. "Conversão de Moedas". Fecha en consulta: 6 agosto de 2018. URL: http://www4.bcb.gov.br/pec/ conversao/conversao.asp

[22] W.F. Sharpe. "Capital asset prices: A theory of market equilibrium under conditions of risk". Journal of Finance. Vol. 19, pp. 425442. 1964. DOI: $10.2307 / 2977928$.

[23] J. Lintner. "The valuation of risk assets and the selection of risky investments in stock portfolios and capital budgets". The Review of Economics and Statistics. Vol. 47, pp. 13-37. 1965. DOI: $10.2307 / 1924119$.

[24] A. Assaf Neto, F.L. Guasti e A.M.A. Procopio. "Uma proposta metodológica para o cálculo do custo de capital no Brasil". Revista de Administração. Vol. 32 No 1, pp. 72-83. 2008.

[25] S.A. Ross, R.W. Westerfield, B.D. Jordan e R. Lamb. "Administração Financeira". AMGH. 10ma edição. Porto Alegre, Brasil. ISBN: 9788580554311. 2015.

[26] J.P. Rosseti et al. "Finanças Corporativas: Teoria e prática empresarial no Brasil". ELSEVIER. 1ra edição. Rio de Janeiro, Brasil. ISBN: 9788535226676. 2008.

[27] D. Simões, R.G. Cervi and G.C. Batistela. "Quantitative analysis of the economic 
risk of sugarcane cultivation for bioethanol production: A case study in Brazil". Bio Resources. Vol. 13 No 3, pp. 6497-6509. 2018.

[28] H. Kierulff. "MIRR: A better measure". Business Horizons. Vol. $51 \mathrm{~N}^{\circ}$ 4, pp. 321-329. 2008. DOI: 10.1016/j.bushor.2008.02.005.

[29] Banco Central do Brasil. "Estatísticas Econômico-Financeiras". Fecha en consulta: 20 de agosto de 2018.URL: https://www3. bcb.gov.br/sgspub/pefi300/telaCtjSelecao. paint

[30] E.F. Brigham e M. Ehrhardt. "Administração Financeira”. Cengage Learning. 3ra edição. São Paulo, Brasil. ISBN: 9788522123919. 2016.

[31] D. Simões, G. Daniluk Mosquera, G.C. Batistela, J.R. de Souza Passos and P.Torres Fenner. "Quantitative analysis of uncertainty in financial risk assessment of road transportation of wood in Uruguay". Forests. Vol. $7 \mathrm{~N}^{\mathrm{o}}$ 7, pp. 1-11. 2016. DOI: 10.3390/ f70 70130.

[32] D.P. Doane e L.E. Seward. "Estatística Aplicada à Administração e Economia". AMGH. 4ta edição. Porto Alegre, Brasil. ISBN: 9788580553932.2014.

[33] G. Box, G.M. Jenkins and G.C. Reinsel."Time Series Analysis: Forecasting and control". Wiley. 5th edition. San Francisco, USA. ISBN: 978-1-118-67502-1. 2015.

[34] G. Schwarz. "Estimating the dimension of a model". Annals of Statistics. Vol. $6 \mathrm{~N}^{\mathrm{o}} 2$, pp. 461-464. 1978.

[35] Palisade Corporation. "Palisade @ Risk for Excel. V. 7.5.1”. Palisade Corporation: Ithaca. New York, USA. 2017.

[36] M. Matsumoto and T. Nishimura. "Mersenne Twister: A 623-dimensionally equidistributed uniform pseudorandom number generator". ACM Transactions on Modeling and Computer Simulation. Vol. 8, pp. 3-30. 1998.

[37] C. Spearman. "General intelligence objectively determined and measured". The American
Journal of Psychology. Vol. 15, pp. 201-292. 1904. DOI: $10.2307 / 1412107$

[38] M.M. Perez e R. Famá. "Características estratégicas dos ativos intangíveis e o desempenho econômico da empresa". UNISANTA Law and Social Science. Vol. 4 No 2, pp. 107-123. 2015.

[39] J. Fermanian. "Measuring agreement between 2 observers: A quantitative case". Revue d'Epidemiologie et de Sante Publique. Vol. 32 N $^{\circ}$ 6, pp. 408-413. 1984.

[40] M.M. Lopes, V.T. Branco e J.B. Soares. "Utilização dos testes estatísticos de Kolmogorov-Smirnov e Shapiro-Wilk para verificação da normalidade para materiais de pavimentação". Transportes. Vol. $21 \mathrm{~N}^{\mathrm{o}} 1$, pp. 59-66. 2013. DOI: 10.4237/transportes. v21i1.566.

[41] I.D.B Silveira e M.D.P. Peters. "Simulação da rentabilidade e viabilidade econômica de um modelo de produção de leite em free-stall". Arquivo Brasileiro de Medicina Veterinária e Zootecnia. Vol. 63 No 2, pp. 392-398. 2011.

[42] C. Lacchini and R. Rüther. "The influence of government strategies on the financial return of capital invested in PV systems located in different climatic zones in Brazil". Renewable Energy. Vol. 83, pp. 786-798. 2015. DOI: 10.1016/j.renene.2015.05.045.

[43] M. Ben-Horin and Y. Kroll. "A simple intuitive NPV-IRR consistent ranking”. The Quarterly Review of Economics and Finance. Vol. 66, pp. 108-114. 2017. DOI: 10.1016/ j.qref. 2017. 01.004.

[44] M.N. Magalhães e A.C.P. Lima. "Noções de probabilidade e estatística". Editora da Universidade de São Paulo. 7 ma edição. São Paulo, Brasil. ISBN: 978-8531406775. 2013.

[45] M.A. Gurau. "The use of profitability index in economic evaluation of industrial investment projects". Proceedings in Manufacturing Systems. Vol. $7 \mathrm{~N}^{\mathrm{o}}$ 1, pp. 55-58. 2012. ISSN: 2067-9238. 